\title{
REGENERATION OF MURINE ERYTHROPOIESIS IN INDIVIDUAL BONE MARROW REGIONS (BONES) AND SPLEEN IN LETHALLY IRRADIATED MARROW GRAFT RECIPIENTS
}

\author{
JIŘIINA HOLÁ, J. VÁCHA, P. LUKÁŠ and V. ZNOJIL \\ Institute of Biophysics of the Czechoslovak Academy of Sciences, 61265 Brno
}

Received April 9, 1984

\begin{abstract}
Holá, Jiřina, Vácha, J., Lukáš, P., Znojil, V.: Regeneration of Murine Erythropoiesis in Individual Bone Marrow Regions (Bones) and Spleen in Lethally Irradiated Marrow Graft Recipients. Acta vet. Brno, 54, 1985: 53-59.

Incorporation of ${ }^{59} \mathrm{Fe}$ into the haeme fraction was measured in various marrow regions (individual bones) and the spleen of mice-recipients of the $\mathrm{C} 57 \mathrm{BL} / 10 \mathrm{ScSnPh}$ strain irradiated with a supralethal gamma exposition, on the 4th, 8th and 11th days after the grafting of syngeneic bone marrow. The ${ }^{59} \mathrm{Fe}$ incorporation (erythropoiesis) reached about $50 \pm 5 \%$ of physiological values in the whole bone marrow and about $350 \pm 70 \%$ in the spleen on the 8th and 11th days. The intensity of marrow erythropoiesis related to the unit bone weight correlates very closely with the intensity of erythropoiesis determined under physiological conditions; the highest was in long bones and spine, the lowest in skull and acral bones. The differences are probably not ascribable to differing cytokinetics of erythroblasts, but rather to differing anatomical structure of bones. The relation of the results to the seeding efficiency of stem cells in different hemopoietic regions is discussed.
\end{abstract}

Marrow transplantation, erythropoiesis in individual bones and spleen, haeme iron, marrow ferrokinetics.

The distribution of haematopoietic stem cells in the body of a lethally irradiated marrow graft recipient is to a large extent unknown. As regards their distribution in various anatomical regions of the bone marrow (in individual bones and bone groups), considerable technical obstacles make experimental analysis difficult. Our original method of haeme extraction from the erythropoietic organs in connection with labelled iron incorporation enables us to analyze the distribution of one at least of the cell lines derived from the injected stem cells, namely the erythropoietic one. In this way it was possible to determine the distribution of the erythropoietic tissue derived from the transplanted syngeneic marrow in the individual bone marrow regions and to compare it with that under physiological conditions. With regard to the clinical use of bone marrow grafting the solution of this question is of some interest not only from the experimental but also the practical point of view.

\section{Material and Methods}

Males of the inbred strain $\mathrm{C} 57 \mathrm{BL} / 10 \mathrm{ScSnPh}$ were used, taken from the Institute's own stock (maintained here since 1960), age 13 weeks, body mass $25.0 \pm 0.7 \mathrm{~g}$. The animals were kept in an air-conditioned room $\left(22^{\circ} \mathrm{C}\right)$ in cages $22 \times 30 \times 44 \mathrm{~cm}$, containing 20 individuals, floor covering wood shavings, diet DOS 2b VELAZ (Prague) containing $6500 \pm 820 \mathrm{nmol} \mathrm{Fe} / \mathrm{g}$.

Two thirds of animals were irradiated with a dose of $9.36 \mathrm{~Gy}$ of gamma rays (Chisostat ${ }^{60} \mathrm{Co}$ source mfd. by Chirana, Prague; the distance from source to body centre was $124 \mathrm{~cm}$, the midline tissue dose rate in open space was $0.544 \mathrm{~Gy} / \mathrm{min}$., measured on a Victoreen 555 exposimeter, Radocon II). One third of the number of experimental animals remained intact.

The isogeneic suspension of bone marrow cells was transplanted to one half of the irradiated mice two hours after irradiation. The shaft of the left femur of the donor mouse was flushed quanti- 
tatively with Hanks' solution, the erythrocytes were haemolyzed with "Zaponin" (Electronics Ltd., U.K.) and the nucleated cells were counted with Coulter Counter (the same mfr.). The nucleated cell suspension was diluted to give a concentration of $1 \times 10^{7} \mathrm{cells} / \mathrm{ml}$ and administered in $0.2 \mathrm{ml}$ volumes into the tail veins of the recipients (i.e., $2 \times 10^{6}$ of marrow cells per mouse). Three experimental groups were thus formed: 1 . intact mice, 2 . lethally irradiated non-transplanted mice, 3. lethally irradiated transplanted mice.

On the 4th, 8th and 11 th days after transplantation three animals from each group were given ${ }^{59} \mathrm{Fe}$-citrate i.p. Ferrous citrate (Messrs Rotop) used was supplied in an isotonic buffer solution containing ascorbic and citric acid $(528 \mathrm{~mol} / \mathrm{mol} \mathrm{Fe}$ and $43.6 \mathrm{~mol} / \mathrm{mol} \mathrm{Fe}$, respectively), pH 5 , specific activity $8.66 \mathrm{MBq} / \mu \mathrm{mol} \mathrm{Fe}$. ${ }^{59} \mathrm{Fe}$ citrate was diluted with saline so as to give $1.11 \times 10^{5} \mathrm{~Bq}$ $(12.8 \mathrm{nmol} \mathrm{Fe})$ per mouse. The solution was administered i.p. in 0.2 -ml volumes.

Six hours after ${ }^{59} \mathrm{Fe}$-citrate administration c. 10 drops of blood were withdrawn from the orbital sinus under ether anaesthesia onto powdered heparin, the erythrocytes washed twice in an excess of saline, and following the final centrifugation $(20 \mathrm{~min}$. at $1,400 \mathrm{~g})$ they were pipetted in amounts of $0.1 \mathrm{ml}$ and haemolyzed with distilled water, and their radioactivity was measured using an Automatic Gamma Well Counting System (Nuclear Chicago) in the range 0.5-1.4 MeV, efficiency $19 \%$. The complete skeleton, free of all soft tissue, was obtained by placing the carcasses in a colony of the beetles Dermestes vulpinus Fbr. (kept according to Grulich 1977). The skeleton was divided into 15 bone groups (see Tab. 1) and the intensity of erythropoiesis in individual groups (and that of the spleen) was ascertained by our method (Vách a et al. 1978). Each sample was frozen in liquid nitrogen and crushed and the haeme iron was extracted with a mixture of ethyl acetate and acetic acid. The efficiency of hemin extraction given by this method is practically quantitative (on average $95 \%$ ). The radioactivity of the $1 \mathrm{ml}$ aliquots was measured.

The radioactivity of the haeme extract of each bone group was expressed as a percentage of the radioactivity administered and from this value the radioactivity pertaining to the erythrocytes circulating in blood vessels of each bone or the spleen was subtracted. This deducted value was calculated from the measured radioactivity of $0.1 \mathrm{ml}$ of erythrocytes and from the known volume of the erythrocytes contained in the circulation in individual bones in animals of the same strain, age and sex (Vácha et al. 1981, Tab. II, bled animals). The magnitude of the deducted values (i.e., of the correction) amounted to $5 \%$ in experimental group 1 , to $0-7 \%$ in group 2 and to $0.3-10 \%$ in group 3 .

The correlations were expressed by means of Spearman's coefficient of rank correlation (Roth et al. 1962).

\section{Results}

The values of the radioactivity of the haeme fraction extracted after 6 - $\mathrm{hr}{ }^{59} \mathrm{Fe}$ incorporation from individual bones, bone groups and the spleen (in $\%$ of the radioactivity administered), after the subtraction of the radioactivity contained in circulating erythrocytes, express the intensity of erythropoiesis in individual regions. They are given for the 4th, 8th and 11th days post transplantation and for all three experimental groups in Tab. 1, together with the weights of bones dried to the constant ones (values taken from Vácha et al. 1981). The bones are grouped for the sake of clarity according to the similarity of their ferrokinetic parameters (Vácha et al. 1984).

It follows from the table that the maximum (plateau) of erythropoiesis is reached in the bone marrow and spleen on the 8th day post transplantation. The maximum corresponds to ca. $50-5 \%$ of the physiological value (incact animals) in the bone marrow, but to about $350 \pm 70 \%$ of that in the spleen. As regards the differences between individual bones, the maximum increase of erythropoiesis against that of the intact controls was found in some acral bones (forefeet, hindfeet, tail vertebrae). The absolute magnitude of erythropoiesis in the spleen roughly equals that of the whole marrow on the 8th and 11 th days.

To make it more significant, the intensity of ${ }^{59} \mathrm{Fe}$ incorporation into the bone marrow was related to the weight of individual bones. The values of this "specific" intensity of erythropoiesis were compared in irradiated (transplanted and non-transplanted) animals to those of intact ones. The specific intensity of erythropoiesis in 
the irradiated transplanted animals is significantly correlated with the intensity of erythropoiesis in intact animals at all post-transplantation intervals. On the 4th day, $\mathrm{r}_{\mathrm{S}}=0.625, \mathrm{P}<0.05$; on the 8th day, $\mathrm{r}_{\mathrm{s}}=0.982, \mathrm{P}<0.01$; on the 11 th day, $\mathrm{r}_{\mathrm{S}}=$ $=0.914, \mathrm{P}<0.01, \mathrm{n}=15$ altogether. The closeness of this correlation is shown graphically for day 8 in Fig. 1.

Some erythropoietic activity is also evident in the irradiated non-transplanted arimals. Here the high correlation of the "specific" erythropoietic activity values with the corresponding ones in the intact animals has also been proven on the 11th posttransplantation day $\left(\mathrm{r}_{\mathrm{s}}=0.789, \mathrm{P}<0.01, \mathrm{n}=15\right)$. However, as the absolute values of ${ }^{59} \mathrm{Fe}$ incorporation in the non-transplanted animals are an order of magnitude lower than those in the transplanted ones (Tab. 1), this spontaneously repopulating erythropoiesis cannot be regarded as responsible for the results obtained in the transplanted animals.

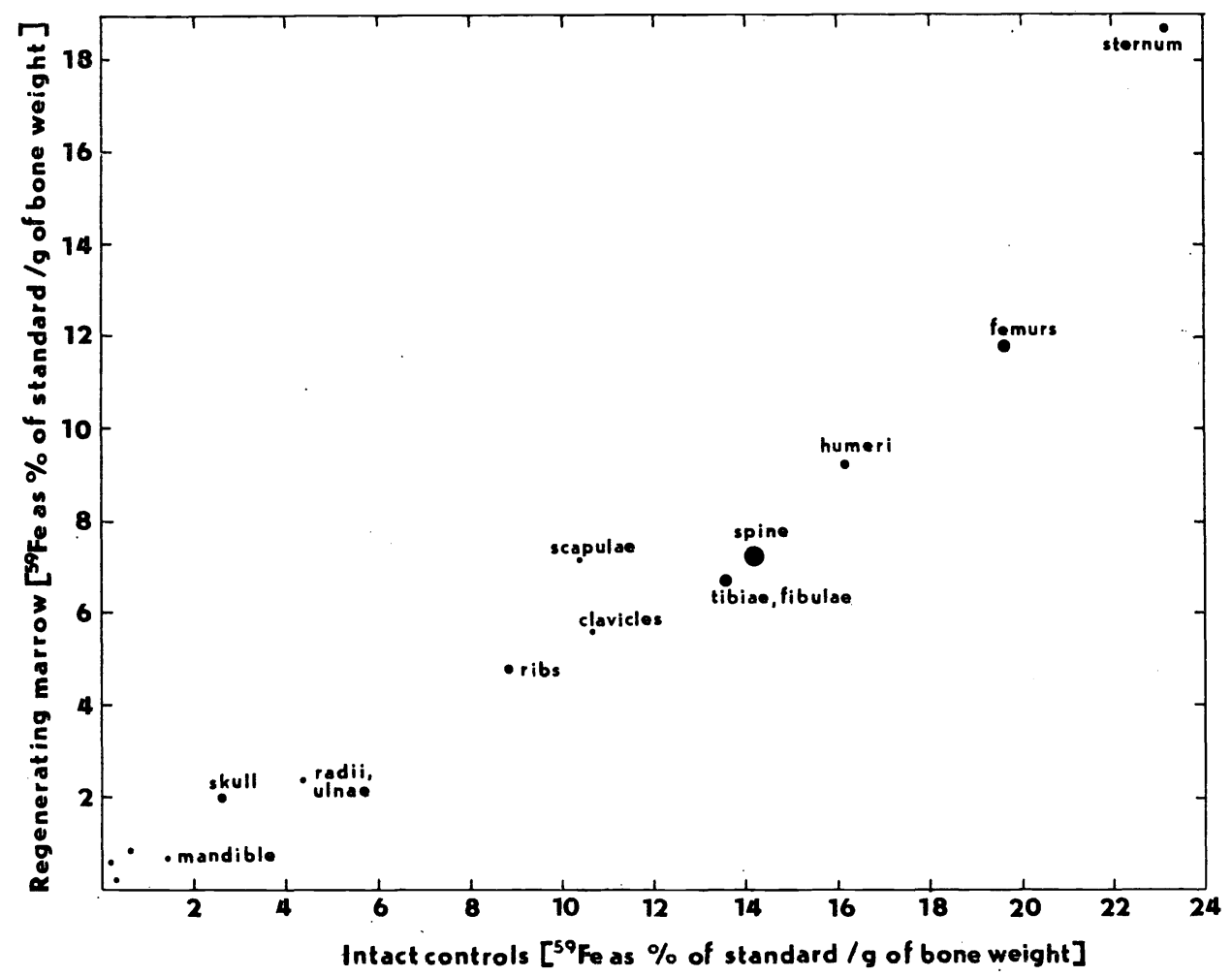

Fig. 1

Correlation between the intensity of ${ }^{59} \mathrm{Fe}$ haeme incorporation (erythropoiesis) as $\%$ of administered radioactivity per $\mathrm{g}$ of bone weight under physiological conditions ( $\mathrm{x}$ - axis) and the degree of regeneration of erythropoiesis after grafting of syngeneic marrow (the same units, y - axis) on the 8th day post transplantation. Areas of circles indicate the absolute value of erythropoiesis in bones under physiological conditions (intact animals). Undescribed points in the left bottom corner fore feet, hind feet, tail vertebrae. Spine - without tail vertebrae, skull - without mandible. 


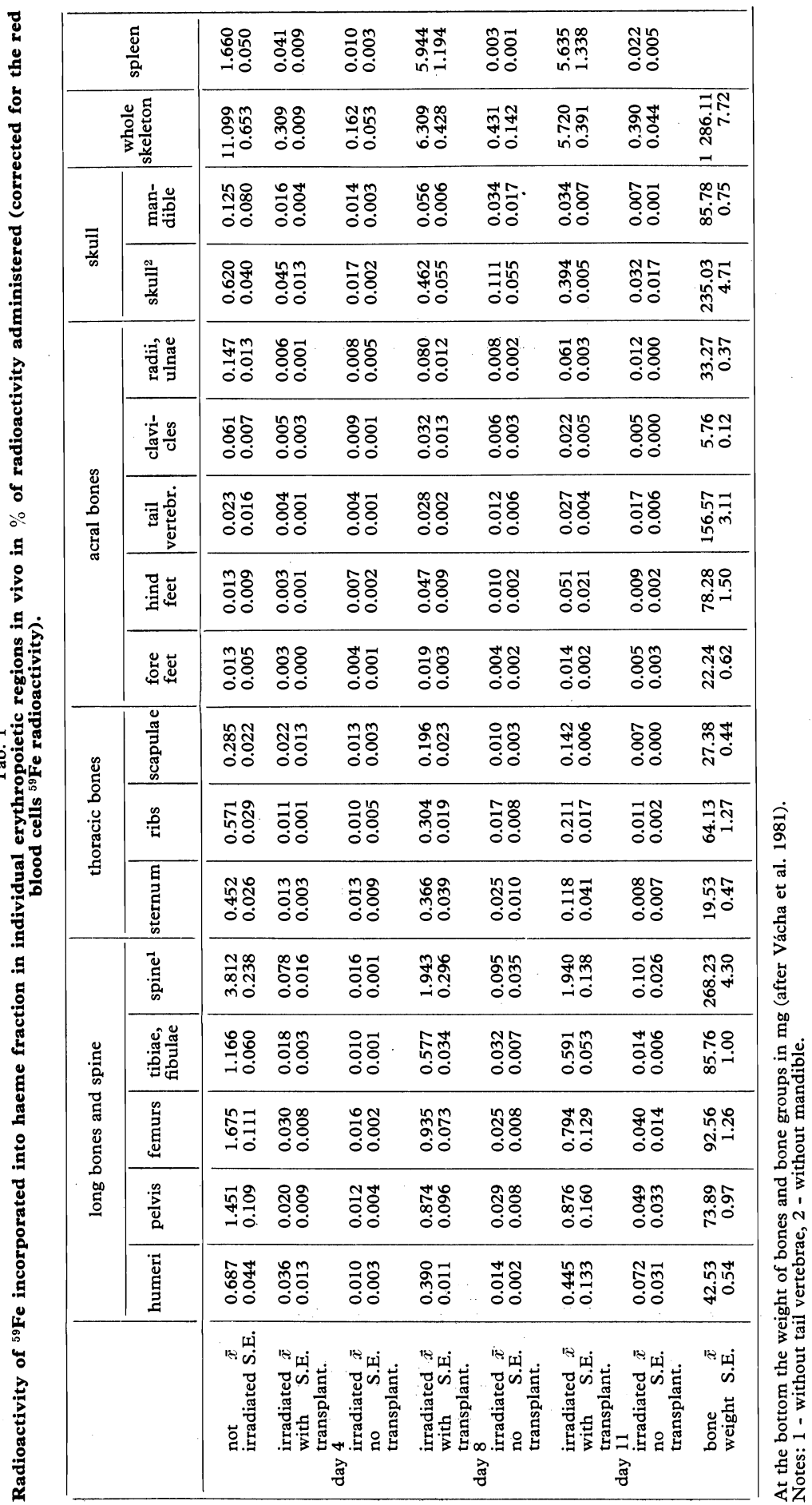




\section{Discussion}

The method of haeme iron extraction connected with subtracting the radioactivity pertaining to the erythrocytes circulating in the vessels of haemopoietic organs could be regarded in our experimental arrangement as an adequate tool for measuring the intensity of erythropoiesis. If some ferrokinetic factors interfere with the ${ }^{59} \mathrm{Fe}$ incorporation results, this distortion is presumably about the same in all bones and in the spleen, as the plasma iron concentration could be considered the same in all regions.

The much higher degree of the regeneration of erythropoiesis in the spleen compared to the marrow on the 8th and 11th days after the syngeneic marrow transplantation corresponds well to our earlier results obtained after acute sublethal irradiation in mice without marrow grafting (summarily Vách a 1982). The regeneration of erythropoiesis in the bone marrow does not reach the control values on the 8th and 11th days, probably because marrow haemopoiesis is exposed to heavy demands for the myeloid cell production during this period (in contradistinction to splenic haemopoiesis). It is known that the CFU-S number in the marrow continues to decline for some time after irradiation, and afterwards remains lower than would correspond to CFU-S proliferation rate (Dr. E. Nečas, personal communication), which can be explained only as a result of a heavy drain on stem cells into the differentiation compartment(s). The spleen is preferentially a red line cell producer, so a lower production load on this organ could be supposed under the given conditions characterized by an enhanced demand for leukopoiesis. Besides this, the spleen can enlarge its volume greatly, unlike the marrow; for both these reasons the repopulation capacity of the erythroblastic and probably also stem cell compartments could be here more rapid and efficient.

The highest regeneration rise of erythropoiesis (as a percentage of the state of rest) in acral bones suggests the presence of some "ectopic" erythropoiesis in acra, apparently as a result of the enhanced demands placed on haemopoiesis under postirradiational conditions, similarily as the hyperregeneration of erythropoiesis in the spleen.

The absolute magnitude of erythropoiesis in the spleen and the bone marrow as a whole is in the ratio of approximately $1: 1$ on the 8th and 11th days post transplantation. It can be guessed from data of Neuwirt and Nečas (1981) that the seeding efficiency of CFU-S in these two organs is in the ratio of about $1: 2$. These and our results are well compatible if we take into account the probable preferential drain on the myeloid precursors from the marrow. The ratios of CFU-S seeding efficiency between individual bones are apparently approximated much more closely by the ratios between ${ }^{59} \mathrm{Fe}$ haeme incorporation in these bones.

By relating the ${ }^{59} \mathrm{Fe}$ incorporation activity to the weight of bones we obtain a more graphic and practically more suitable notion of the "specific" intensity of erythropoiesis in the individual bones. It is only an approximation of course, as the ratio between the erythroid marrow weight and that of the rest of the bone is unknown. It follows from the high degree of correlation between the "specific" intensity of erythropoiesis in the marrow under physiological conditions and after marrow transplantation in irradiated recipients that erythropoiesis regenerates from the received syngeneic marrow proportionately to the magnitude of erythropoiesis present in the corresponding marrow region, even under physiological conditions. It follows from Fig. 1 that the same bones have a high specific intensity of erythropoiesis under physiological conditions and during regeneration (besides the sternum they are the long bones and the spine without the tail); these are followed by the scapulae and ribs, while the acral bones have the lowest erythropoiesis per unit weight under both conditions (in spite of the indication mentioned of ectopic erythropoiesis in acra in transplanted 
animals). The specific intersity of erythropoiesis ascertained in intact animals ard in irradiated trarsplarted ores in present experimerts is correlated very closely (as might be expected) with the flow of iron destined for haeme production per unit bone weigh.t, which we determined previously in intact mice by means of the mathematical modelling of marrow ferrokinetics (Vácha et al. 1984, Tab. 1, the flow marked as $\mathrm{A} 3 / \mathrm{M})$. The corresponding correlation coefficierts are: intact animals, $r_{\mathrm{s}}=0.971$, animals 8th day post transplartation, $\mathrm{r}_{\mathrm{s}}=0.952 ; \mathrm{n}=15, \mathrm{P}<0.01$ in both cases. - We found in the last mentioned paper that the half time of the efflux of haeme iron from the bones of varigus types (as a component of reticulocytes released) is nearly identical. This suggests that the cytokinetics of erythroblasts is very similar in all marrow erythropoietic regions. The specific intensity of erythropoiesis thus differs between bones apparently mainly because the haemopoietic marrow represents a different fraction of the total bone mass, possibly because erythropoiesis is differently represented in the haemopoietic marrow of bones of various types. The conspicuous connection between several ferrokinetic parameters and the anatomical bone type (Váchà et al. 1984, Tab. 1) suggests this possibility. If there were no factor permanently present in the bones themselves determining the intensity of erythropoiesis per unit bone weight, the incessant circulation of stem cells in blood would level out the differences between bones sooner or later.

The simplest explanation of the present observations on the different marrow regions is therefore that the population of erythroblasts derived from the graft in a specific bone behaves in the same manner relative to other localities as would the population of cells physiologically present in this region under rest conditions. In bones in which there are conditions favourable to a higher intensity of erythropoiesis per unit weight under physiological conditions, there are also conditions favourable to the more intensive repopulation of the erythroblastic series derived from the grafted marrow.

\section{Regenerace erytropoesy u myší v jednotlivých lokalitách kostní dřeně (kostech) a ve slezině u letálně ozářených příjemcủ kostní dřeně}

U myší-příjemců kmene $\mathrm{C} 57 \mathrm{BL} / 10 \mathrm{ScSnPh}$ ozářených supraletální gama exposicí byla 4., 8. a 11. den po podání syngenní kostní dřeně měřena inkorporace ${ }^{59} \mathrm{Fe}$ do hemové frakce ve všech lokalitách-dřeně ( $v$ jednotlivých kostech) a ve slezině. V 8 . a 11. dni dosáhla inkorporace ${ }^{59} \mathrm{Fe}$ (erytropoesa) okolo $50 \pm 5 \%$ fysiologických hodnot v kostní dřeni a okolo $350 \pm 70 \%$ ve slezině. Intensita dřeňové erytropoesy přepočtená na jednotku hmotnosti kosti těsně korelovala s intensitou erytropoesy zjištěnou za fysiologických podmínek; byla nejvyšší v dlouhých kostech končetin, sternu a v páteři a nejnižší $\mathrm{v}$ lebce a akrálních kostech. Rozdíly nejsou pravděpodobně způsobeny rozdílnou cytokinetikou erytroblastů, ale spíš rozdílnými anatomickymi poměry v utváření kostí. Je diskutován vztah těchto výsledků z hlediska účinnosti osazení kmenových buněk v jeduotlivých hemopoetických lokalitách.

\section{Регенерация эритропоэза у мышей в отдельных участках костного мозга (костях) и в селезенке у летально облученных реципиентов костного мозга}

У мышей-реципиентов линии $\mathrm{C} 57 \mathrm{BL} / 10 \mathrm{ScSnPh}$, облученных супралетальными экспозициями гамма-лучей, на 4, 8 и 11-е сутки после введения сингенного костного мозга измерялась инкорпорация ${ }^{59} \mathrm{Fe}$ в гемовую 
фракцию во всех участках мозга (в отдельных костях) и в селезенке. На 8-е и 11 -е сутки инкорпорация ${ }^{59} \mathrm{Fe}$ (эритропоэз) достигала около $50 \pm 5 \%$ физиологических величин в костном мозге и около $350 \pm 70 \%$ в селезенке. Интеноивность эритропоэза в костном мозге, расчитанная на единицу массы кости, находилась в тесной корреляции с интенсивностью эритропоэза, определенного при физиологических условиях ; самая большая интенсивность была определена в длинных костях конечностей, грудной кости и в позвоночнике, а самая низкая - в черепе и акральных костях. Различия по всей вероятности не способствованы различной кинетикой эритробластов, но скорее всего различными анатомическими отношениями в структуре костей. Обсуждаются отношения этих результатов с точки зрения эффективности осаждения стволовых клеток в отдельных участках гемопоэза.

\section{References}

GRULICH, I.: Osteologische Präparation mit der Verwendung der kadaverikolen Käfer (Dermestes vulpinus Fbr., Coleoptera, Insecta). Lynx (Prague) n.s., 19/1977, 1977: 87-98.

NEUWIRT, J. - NEČAS, E.: Stem Cells and Diseases of Blood. Avicenum, Praha, 1981, p. 107 (in Czech).

ROTH, Z. - JOSÍFKO, M. - MALÝ, V. - TRČKA, V.: Statistické metody v experimentální medicíně. Státní zdravotnické nakladatelství, Praha, 1962, p. 182.

VÁCHA, J.: Postirradiational Oscillations of Erythropoiesis in Mice. Academia, Praha, 1982.

VÁCHA, J. - DUNGEL, J. - KLEINWÄCHTER, V.: Determination of heme and non-heme iron content of mouse erythropoietic organs. Exp. Hemat., 6: 718 -724, 1978.

VÁCHA, J. - HOLÁ, J. - DUNGEL, J. - ZNOJIL, V.: Distribution of periph ral blood in the erythropoietic organs of mice. Scripta Medica (Brno), 54: 283-194, 1981.

VÁCHA, J. - ZNOJIL, V. - HOLÁ, J. - DUNGEL, J.: Iron kinetics in individual bone marrow regions (bones) in mice. Acta Vet. Brno, 53, 1984, 119-136. 